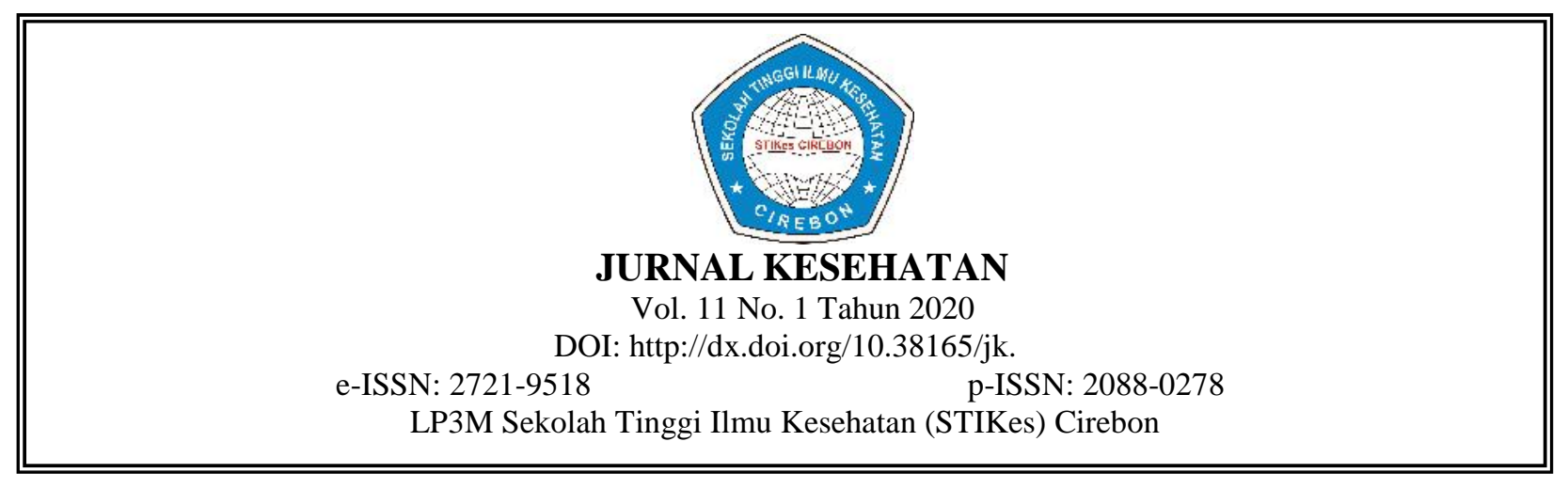

\title{
HUBUNGAN TINGKAT PENGETAHUAN DAN PENDIDIKAN DENGAN PENGELOLAAN OBAT DI PUSKESMAS
}

\author{
Herlinawati ${ }^{*}$ \\ Program Studi Kesehatan Masyarakat, Sekolah Tinggi Ilmu Kesehatan Cirebon \\ linacirebon57@gmail.com \\ Siska Anjar Lestari ** \\ Program Studi Kesehatan Masyarakat, Sekolah Tinggi Ilmu Kesehatan Cirebon
}

\begin{abstract}
Abstrak
Pengelolaan obat memiliki peranan dalam memelihara dan meningkatkan penggunaan obat secara rasional dan ekonomis di puskesmas dan unit kesehatan lain melalui penyediaan obat-obatan yang tepat jenis, tepat jumlah, tepat waktu dan tempat. Pengelolaan obat dapat dipengaruhi oleh tingkat pengetahuan dan pendidikan pengelola obat, jika tingkat pengetahuan dan pendidikan tinggi maka kemampuan pengelolaan obat oleh pengelola unit farmasi juga tinggi.Penelitian ini bertujuan untuk mengetahui tingkat pengetahuan dan pendidikan terhadap pengelola obat di puskesmas. Penelitian ini merupakan penelitian observasional analitik melalui pendekatan cross sectional. Peneliti melakukan Penelitian di Puskesmas Se-Wilayah Kabupaten Kuningan dengan populasi petugas pengelola obat yang berjumlah 53 orang, dan sampel yang digunakan adalah total sampling, sejumlah 53 orang. Instrumen menggunakan kuesioner.Teknik pengambilan data dilakukan dengan metode penyebaran angket. Data dianalisis menggunakan uji statstik Continuity Correction atau Yates Correlation pada $\alpha=5 \%$. Hasil penelitian ini didapat tingkat pengetahuan tentang pengelolaan obat di Puskesmas sebagian besar kategori kurang baik (71,7\%), pendidikan pengelolaan obat di Puskesmas sebagian besar non apoteker $(60,4 \%)$, pengelolaan obat di Puskesmas sebagian besar kategori kurang baik $(67,9)$. Hasil uji statistic dengan chi-square didapatkan ada hubungan antara tingkat pengetahuan dengan pengelolaan obat ( $\mathrm{p}$ value) $0,000<0,05$ dan ada hubungan antara pendidikan dengan pengelolaan obat ( $\mathrm{p}$ value) $0,001<0,05$.
\end{abstract}

Kata Kunci :Pengetahuan, Pendidikan dan Pengelolaan Obat

\begin{abstract}
Drug management has a role in maintaining and increasing the use of drugs rationally and economically in health centers and other health units through the provision of the right type of medicine, the right amount, the right time and place. Drug management can be influenced by the level of knowledge and education of drug managers, if the level of knowledge and education is high then the ability og drug management by pharmaceutical unit managers is also high. This study aims to determine the knowledge and education of drug managers in health centers. This research was an observational analytic study through a cross sectional approach. Researchers conducted research in Kuningan District Health Center with 53 people, and the sampel used was a total sampling of 53 people. The instrument uses a questionnaire. The data collection technique wa carried out using the method of distributing questionnaires. Data were analyzed using a statistical test Continuity Correction or Yates Correlation $\alpha 5 \%$. The results of this study obtained knowledge about the management of drugs in the health center most of the categories are not good (71,7\%), education management of the drug at the health center are mostly non-pharmacists $(60,4 \%)$, drug management at the health center is mostly not good category $(67,9)$. With the results of the chi-square statistical test it was found that there was a relationship between knowledge and drug management ( $p$ value) $0,000<0,05$, there was a relationship between education and drug management ( $p$ value) 0,001 <0,05.
\end{abstract}

Keywords: Knowledge, Education and Drug Management 


\section{PENDAHULUAN}

Pengelolaan obat memiliki peranan dalam memelihara dan meningkatkan penggunaan obat secara rasional dan ekonomis di unit-unit pelayanan kesehatan melalui penyediaan obat-obatan yang tepat jenis, tepat jumlah, tepat waktu dan tempat. Laporan Pemakaian dan Lembar Permintaan Obat (LPLPO) merupakan salah satu contoh pengelolaan obat yang bermanfaat untuk mengendalikan tingkatan stok, perencanaan distribusi, perencanaan kebutuhan obat dan memantau penggunaan obat. Terlaksananya pengelolaan obat dengan efektif dan efisien perlu ditunjang dengan sistem informasi manajemen obat untuk menggalang keterpaduan pelaksanaan kegiatankegiatan pengelolaan obat. Adanya sistem ini membuat pelaksanaan salah satu kegiatan pengelolaan obat dapat dengan mudah diselaraskan dengan yang lain. ${ }^{1}$

Pengelolaan obat di unit layanan kesehatan memiliki beberapa dampak positif yaitu: terlaksananya peresepan yang rasional; pengembangan dan peningkatan pelayanan obat yang dapat menjamin beberapa hal yaitu penyerahan obat yang benar kepada pasien, dosis dan jumlah yang tepat, wadah obat yang baik yang dapat menjamin mutu obat, dan informasi yang jelas dan benar kepada pasien; serta meningkatkan efisiensi penggunaan obat. Pengelolaan obat yang tidak baik di unit layanan kesehatan dapat memberikan dampak negatif baik secara medik maupun ekonomi. Dampak negatif secara medik yaitu menurunnya mutu pelayanan kepada pasien atau masyarakat sedangkan dampak negatif secara ekonomi yaitu inefisiensi biaya operasional pada unit layanan kesehatan dengan adanya kebocoran anggaran logistik obat. ${ }^{1}$

Faktor-faktor yang mempengaruhi pengelolaan obat meliputi delapan hal yaitu: dana pengadaan dan pengelolaan obat, tata kelola instalasi farmasi, pendidikan personel, kualitas pengelola obat, lama kerja personel, sarana pengelolaan obat, administrasi pengelolaan obat dan pengetahuanpengelolaobat. ${ }^{2}$ Pengelolaan obat dipengaruhi pula oleh tingkat pengetahuan pengelola obat, jika tingkat pengetahuan tinggi maka kemampuan pengelolaan obat oleh pengelola unit farmasi juga tinggi.

Di Indonesia pengelolaan obat yang dilakukan oleh pengelola obat khususnya pada puskesmas masih tergolong kurang baik ini dibuktikan dengan penelitian yang dilakukan oleh Suryawati dan Anisa yang melakukan penelitian di 4 kabupaten yaitu Sleman, Banyumas, Kulon Progo dan Kudus sebagian besar penggunaan obat yang dilakukan di 4 kabupaten tersebut menggunakan obat dengan nama dagang sehingga terjadi peningkatan biaya obat pada tiap resep, serta peningkatan obat non esensial dan peningkatan penggunaan antibiotik pada masyarakat. Berdasarkan penelitian tersebut hal ini disebabkan karena di puskesmas lebih kurang 50\% tenaga pengelola obatnya tidak memiliki latar belakang pendidikan farmasi. ${ }^{4}$

Pada tahun 2011 di seluruh Puskesmas di Indonesia menunjukkan bahwa hanya 17,5\% puskesmas di Indonesia yang memiliki apoteker dan ada sekitar 32,2\% puskesmas yang tidak memiliki tenaga kefarmasian sama sekali. Berdasarkan riset tersebut juga dikatakan bahwa apoteker berperan lebih baik dalam memberikan pelayanan farmasi, mengelola obat dan menyusun Lembar Pemakaian dan Lembar Permintaan Obat (LPLPO) dengan lengkap dibandingkan dengan tenaga teknis kefarmasian dan tenaga teknis kefarmasian juga berperan lebih baik dibandingkan dengan tenaga non-farmasi dalam hal yang sama. ${ }^{5}$

Berdasarkan profil tenaga kefarmasian provinsi yang ada di Indonesia Provinsi Jawa Barat memiliki puskesmas sebanyak 1.056 unit, yang mana hanya 16,1\% Puskesmas yang memiliki apoteker dan hanya 65,6\% mempunyai tenaga teknis farmasi sisanya sebanyak 18,2\% puskesmas tidak ada apoteker ataupun tenaga teknis kefarmasian sama sekali. ${ }^{5}$ Kabupaten Kuningan sendiri memiliki 37 unit puskesmas dengan puskesmas rawat inap sebanyak 6 unit dan puskesmas non rawat inap sebanyak 31 unit. Berdasarkan jumlah tenaga kefarmasian yang ada di Kabupaten Kuningan terdapat 29 orang tenaga farmasi, 23 orang asisten farmasi dan 22 orang perawat yang bekerja di Puskesmas Se-Wilayah Kabupaten Kuningan, tetapi pada beberapa puskesmas tidak memiliki tenaga apoteker. ${ }^{6}$

Hasil observasi yang dilakukan oleh penelitimenunjukanpengelolaanobat di Puskesmas SeWilayah Kabupaten Kuningan belum dilaksanakan secara baik sebagaimana ditunjukan adanya permasalahan yang dihadapi yaitu terjadinya ketidakcukupan obat atau penyediaan stok obat yang 
berlebihan pada beberapa Puskesmas. Permasalahan ini terjadi karena dalam melakukan permintaan dalam setiap periode distribusi pengelola obat Puskesmas tidak memperhitungkan stok optimum, artinya pengelola obat tidak memperhitungkan waktu tunggu dan waktu kekosongan obat, hal ini mengakibatkan ketersediaan obat di puskesmas ada yang berlebih dan ada yang kurang.

Banyak faktor yang mempengaruhi pengelolaan obat, diantaranya tingkat pengetahuan dan pendidikan. Penelitian Aryani menunjukkan bahwa ada hubungan antara tingkat pengetahuan pengelola unit farmasi terhadap pengelolaan obat. ${ }^{3}$ Penelitian Aziz menunjukkan bahwa terdapat hubungan yang bermakna antara faktor pendidikan dengan kinerja pengelolaan obat di Puskesmas ${ }^{7}$ dan penelitian Waluyo menunjukkan bahwa faktor yang mempengaruhi pengelolaan obat diantaranya pendidikan staf/personel. ${ }^{2}$

Tujuan penelitian ini adalah untuk mengetahui hubungan tingkat pengetahuan dan pendidikan dengan pengelolaan obat di Puskesmas Wilayah Kerja Dinas Kesehatan Kabupaten Kuningan Tahun 2019.

\section{METODE PENELITIAN}

Rancangan penelitian ini menggunakan jenis penelitian analitik dengan pendekatan cross sectional. Variabel yang akan diteliti adalah tingkat pengetahuan dan pendidikan sebagai variabel bebas dan pengelolaan obat sebagai variabel terikat. Populasi penelitian adalah seluruh pengelola obat di Puskesmas Wilayah Kerja Dinas Kesehatan Kabupaten Kuningan sebanyak 53 orang.Teknik pengambilan sampel pada penelitian ini menggunakan teknik total sampling yaitu cara pengambilan sampel bila semua populasi diteliti. ${ }^{8}$ Jadi sampel penelitian ini berjumlah 53 orang. Instrumen penelitian yang digunakan untuk memperoleh data adalah kuesioner. Metode pengumpulan data yang digunakan dalam penelitian ini adalah data primer dan data sekunder. Data primer adalah data yang diperoleh secara langsung dengan cara menyebarkan kuesioner/angket sedangkan data sekunder adalah data yang diperoleh dari Dinas Kesehatan Kabupaten Kuningan dan Puskesmas SeWilayah Kabupaten Kuningan. Untuk mengetahui hubungan antara variabel bebas dan variabel terikat digunakan uji statistik chi squre (Yates Correlationuntuk table 2x2) dengan alpha 5\%.

\section{HASIL PENELITIAN}

\section{Tingkat Pengetahuan tentang Pengelolaan Obat}

Tabel 1 Distribusi Frekuensi Tingkat Pengetahuan Responden tentang Pengelolaan Obat

\begin{tabular}{|c|c|c|}
\hline Tingkat Pengetahuan & $\mathrm{n}$ & Persentase $(\%)$ \\
\hline Kurang Baik & 38 & 71,7 \\
\hline Baik & 15 & 28,3 \\
\hline Total & 53 & 100 \\
\hline
\end{tabular}

Tabel 2 menunjukkan bahwa responden yang memiliki tingkat pengetahuan kurang baik adalah sebesar $71,7 \%$, lebih tinggi dibandingkan responden yang memiliki tingkat pengetahuan baik sebesar $28,3 \%$.

\section{Pendidikan}

Tabel 2 Distribusi Frekuensi Responden Berdasarkan Pendidikan

\begin{tabular}{|c|c|c|}
\hline Pendidikan & $\mathrm{n}$ & Persentase $(\%)$ \\
\hline Apoteker & 21 & 39,6 \\
\hline Non Apoteker & 32 & 60,4 \\
\hline Total & 53 & 100 \\
\hline
\end{tabular}

Tabel 2 menunjukkan bahwa frekuensi responden yang memiliki pendidikan non apoteker JURNAL KESEHATAN Vol. 11 No. 1 Tahun 2020 | 45 
$(60,4 \%)$ lebih tinggi dibandingkan dengan yang memiliki pendidikan apoteker $(39,6 \%)$.

\section{Pengelolaan Obat}

Tabel 3 Distribusi Frekuensi Responden dalam Pengelolaan Obat

\begin{tabular}{lccc}
\hline \multicolumn{1}{r}{ Pengelolaan } & $\mathrm{n}$ & Persentase (\%) \\
\hline Kurang Baik & & 36 & 67,9 \\
Baik & 17 & 32,1 \\
\hline \multicolumn{2}{c}{ Total } & 53 & 100 \\
\hline
\end{tabular}

Tabel 3 menunjukkan bahwa responden yang memberikan interpretasi pengelolaan obat kurang baik $(67,9 \%)$, lebih tinggi dari responden yang memberikan interpretasi pengelolaan obat baik $(32,1 \%)$.

\section{Hubungan Tingkat Pengetahuan dengan Pengelolaan Obat}

Tabel 4 Hubungan Tingkat Pengetahuan dengan Pengelolaan Obat

\begin{tabular}{lccccccc}
\hline & \multicolumn{3}{c}{ Pengelolaan Obat } & & & \\
Tingkat Pengetahuan & Kurang Baik & Baik & & & \\
& $\mathrm{n}$ & $\%$ & $\mathrm{n}$ & $\%$ & $\mathrm{n}$ & $\%$ & P value \\
\hline Kurang Baik & 33 & 91,7 & 5 & 8,3 & 38 & 100 & 0,000 \\
Baik & 3 & 29,4 & 12 & 70,6 & 15 & 100 & \\
\hline Total & 36 & 71,7 & 17 & 28,3 & 53 & 100 & \\
\hline
\end{tabular}

Tabel 4 menunjukkan bahwa responden yang memiliki tingkat pengetahuan kurang baik, sebagian besar $(91,7 \%)$ menyatakan pengelolaan obatnya kurang baik. Sedangkan responden yang memiliki tingkat pengetahuan baik, sebagian besar (70,6\%) menyatakan pengelolaan obatnya baik. Hasil uji statistic dengan chi-square yang menunjukkan nilai signifikansinya sebesar 0,000 $(p<0,05)$ yang berarti ada hubungan yang signifikan antara tingkat pengetahuan tentang pengelolaan obat dengan pengelolaan obat di Puskesmas.

\section{Hubungan Pendidikan dengan Pengelolaan Obat}

Tabel 5 Hubungan Pendidikan dengan Pengelolaan Obat

\begin{tabular}{|c|c|c|c|c|c|c|c|}
\hline \multirow{3}{*}{ Pendidikan } & \multicolumn{4}{|c|}{ Pengelolaan Obat } & \multirow{2}{*}{\multicolumn{2}{|c|}{ Total }} & \multirow{3}{*}{$P$ value } \\
\hline & \multicolumn{2}{|c|}{ Kurang Baik } & \multicolumn{2}{|c|}{ Baik } & & & \\
\hline & $\mathrm{n}$ & $\%$ & $\mathrm{n}$ & $\%$ & $\mathrm{n}$ & $\%$ & \\
\hline Apoteker & 12 & 33,3 & 15 & 88,2 & 27 & 100 & \\
\hline Non Apoteker & 24 & 66,7 & 2 & 11,8 & 26 & 100 & 0,001 \\
\hline Total & 36 & 67,9 & 17 & 32,1 & 53 & 100 & \\
\hline
\end{tabular}

Tabel 5 menunjukkan bahwa responden yang memiliki pendidikan apoteker, sebagian besar 
$(88,2 \%)$ menyatakan bahwa pengelolaan obatnya baik. Sedangkan responden dengan pendidikan non apoteker, sebagian besar $(66,7 \%)$ menyatakan pengelolaan obatnya kurang baik. Hasil uji statistic dengan chi-square yang menunjukkan nilai signifikansinya sebesar $0,001(p<0,05)$ yang berarti ada hubungan yang signifikan antara pendidikan dengan pengelolaan obat.

\section{PEMBAHASAN}

\section{Tingkat Pengetahuan tentang Pengelolaan Obat}

Berdasarkan hasil penelitian ini menunjukkan bahwa responden yang mempunyai tingkat pengetahuan tentang pengelolaan obat yang kurang baik sebanyak 38 responden $(71,7 \%)$, lebih tinggi dibandingkan dengan responden yang memiliki tingkat pengetahuan yang baik sebanyak 15 responden $(28,3 \%)$. Hasil penelitian tersebut menggambarkan bahwa responden menilai dan menyatakan bahwa tingkat pengetahuan tentang obat di Puskesmas Se-Wilayah Kabupaten Kuningan termasuk dalam kategori kurang baik.

Kurang baiknya pengetahuan tentang obat akan berdampak pada proses pengelolaan obat, mulai dari perencanaan, pengadaan, penyimpanan, sampai pendistribusian obat. Apabila pengetahuan tentang tata kelola obat kurang baik, maka para petugas pengelola obat akan kebingungan dalam mengelola ketersediaan obat, penyimpanan obat, pendistribusian obat, serta pelayanan terhadap pasien menyebabkan pengelolaan obat akan terhambat, sehingga akan berdampak besar pada proses pelayanan kesahatan pada pasien.

Dalam upaya meningkatkan pengetahuan tentang pengelolaan obat, maka Puskesmas dapat menyelenggarakan berbagai program dan kegiatan seminar, pelatihan, workshop dan lainnya, sehingga diharapkan seluruh petugas pengelolaan obat dapat bekerja secara profesional dengan pemahaman dan memiliki pengalaman yang cukup dalam mengelola obat.

\section{Pendidikan}

Berdasarkan hasil penelitian ini menunjukkan bahwa responden yang memiliki pendidikan apoteker sebanyak 21 responden $(49,1 \%)$, dan responden yang pendidikannya non apoteker sebanyak 32 responden $(50,9 \%)$. Hasil penelitian ini menggambarkan bahwa tingkat pendidikan petugas pengelolaan obat lebih dari sebagian memiliki latar belakang pendidikan non apoteker.

Hasil penelitian tersebut mempertegas pentingnya pendidikan. Dimana melalui pendidikan, petugas pengelola obat akan mampu mengembangkan potensi yang dimilikinya termasuk potensi emosional, pengetahuan, sikap dan keterampilannya, sehingga ia akan mampu bekerja sesuai dengan standarisasi yang telah ditetapkan dan menghasilkan kinerja yang optimal. ${ }^{9}$

Kekurangan tenaga apoteker di Puskesmas akan berdampak pada terhambatnya proses pengelolaan obat. Petugas pengelola obat yang non apoteker kecenderungan tidak faham secara detail tentang proses pengelolaan obat. Akibat yang sering muncul adalah manajemen pengelolaan obat yang tidak efektif dan tidak efisien, sehingga seringkali terjadi kelebihan stok obat atau kekurangan obat. Hal tersebut tentunya akan berdampak negatif pada keuangan dan pelayanan puskesmas.

\section{Pengelolaan Obat}

Berdasarkan hasil penelitian ini menunjukkan bahwa pengelolaan obat yang termasuk kategori kurang baik sebanyak 36 responden $(67,9 \%)$, dan pengelolaan obat yang termasuk kategori baik sebanyak 17 responden (32,1\%). Maka dapat disimpulkan bahwa pengelolaan obat di Puskesmas Se-Wilayah kabupaten Kuningan termasuk kategori kurang baik.

Pengelolaan obat terdiri dari beberapa unsur yang saling berkaitan satu sama lain yaitu: perencanaan, permintaan, penerimaan, penyimpanan, distribusi, pengendalian penggunaan serta pencatatan dan pelaporan. ${ }^{4}$ Sehingga apabila pengelolaan obat kurang baik di Puskesmas dapat memberikan dampak negatif baik secara medik maupun ekonomi. Dampak negatif secara medik yaitu menurunnya mutu pelayanan kepada pasien atau masyarakat sedangkan dampak negatif secara ekonomi yaitu inefisiensi biaya operasional pada unit layanan kesehatan dengan adanya kebocoran anggaran logistik obat. 
Langkah-langkah yang dapat dilaksanakan dalam upaya meningkatakan kualitas pengelolaan obat diantaranya adalah melalui peningkatan pengetahuan bagi petugas pengelola obat, melalui peningkatan standar pendidikan petugas pengelola obat, idealnya berpendidikan sebagai apoteker, melalui evaluasi dan pengawasan pengelolaan obat secara baik dan ketat.

\section{Hubungan Tingkat Pengetahuan dengan Pengelolaan Obat}

Hasil penelitian menunjukkan bahwa ada hubungan yang signifikan antara tingkat pengetahuan tentang pengelolaan obat dengan pengelolaan obat di Puskesmas. Hasil penelitian ini sesuai dengan hasil penelitian Aryani et al (2016) yang menemukan adanya hubungan yang bermakna antara tingkat pengetahuan pengelolaan obat terhadap pengelolaan obat Puskesmas di Kabupaten Banyumas. ${ }^{3}$

Hal tersebut searah dengan pendapat yang menyatakan bahwa terjadinya tindakan seseorang antara lain dipengaruhi oleh pengetahuan, sikap, keyakinan, kepercayaan, nilai-nilai, tradisi dan sebagainya yang berkaitan dengan kesehatan.Faktor- faktor tersebut terutama yang positif mempermudah terwujudnya perilaku. Pengetahuan yang dimiliki seseorang merupakan pemicu awal tingkah laku termasuk tingkah laku dalam bekerja. Pengetahuan sangat diperlukan dalam perubahan pola pikir dan perilaku. ${ }^{10}$

\section{Hubungan Pendidikan dengan Pengelolaan Obat}

Hasil penelitian menunjukkan bahwa ada hubungan yang signifikan antara pendidikan dengan pengelolaan obat. Hasil penelitian tersebut sejalan dengan hasil penelitian yang dilakukan oleh Waluyo (2015), menunjukkan tingkat Pendidikan berpengaruh terhadap kemampuan pengelolaan obat. $^{11}$

Hal tersebut searah dengan pendapat yang dikemukakan oleh ahli yang menjelaskan bahwa pendidikan memiliki hubungan dengan pengelolaan obat. Tingkat pendidikan seseorang akan berpengaruh terhadap perkembangan potensi yang dimilikinya termasuk potensi emosional, pengetahuan, sikap dan keterampilan. Hal ini tentunya dapat berdampak terhadap pelaksanaan pekerjaanya/hasil kerjanya. ${ }^{10}$

\section{SIMPULAN}

1. Tingkat pengetahuan tentang pengelolaan obat di Puskesmas Se-Wilayah Kabupaten Kuningan sebagian besar termasuk kategori kurang baik $(71,7 \%)$.

2. Pendidikan pengelola obat di Puskesmas Se-Wilayah Kabupaten Kuningan sebagian besar non apoteker $(60,4 \%)$.

3. Pengelolaan obat di Puskesmas Se-Wilayah kabupaten Kuningan sebagian besar termasuk kategori kurang baik $(67,9 \%)$.

4. Ada hubungan antara tingkat pengetahuan dengan pengelolaan obat di Puskesmas ( $p v a l u e=$ $0,000<0,05)$.

5. Ada hubungan antara pendidikan dengan pengelolaan obat di Puskesmas ( $p$ value $=0,001<$ $0,05)$.

\section{SARAN}

\section{Bagi Puskesmas}

Puskesmas diharapkan dapat melaksanakan secara mandiri atau mengajukan permohonan kepada Dinas Kesehatan sebagai induk organisasi untuk menyelenggarakanberbagai program dan kegiatan pelatihan, seminar dan sejenisnya serta peningkatan standar pendidikan yang diperuntukan bagi petugas pengelolaan obat, sehingga diharapkan pengelolaan obat dapat dilaksanakan dengan lebih baik.

2. Bagi Dinas Kesehatan

Hasil penelitian ini dapat menjadi referensi dalam pengambilan keputusan dan kebijakan terkait 
pelaksanaan program dan kegiatan dalam upaya peningkatan kualitas pengelolaan obat melalui penambahan sumber daya apoteker serta melalui penyelenggaraan pelatihan, seminar, workshop dan lainnya yang diperuntukan bagi para petugas obat di Puskesmas yang ada di Wilayah Kabupaten Kuningan.

3. Responden

Diharapkan para petugas pengelolaan obat dapat meningkatkan pemahaman tentang tugas dan fungsinya melalui berbagai langkah-langkah yang progresif, baik melalui pelatihan, seminar, workshop ataupun melalui peningkatan tingkat pendidikan, dengan cara melanjutkan sekolah yang lebih tinggi.

\section{DAFTAR PUSTAKA}

1. Anonim. Pengelolaan Obat [Internet]. [cited 2019 Jan 11]. Available from: https://layanankefarmasian.blogspot.com

2. YW W. Analisis faktor yang mempengaruhi pengelolaan obat publik di Instalasi Farmasi Kabupaten (Studi di Papua Wilayah Selatan). J Ilmu Kefarmasian Indones. 2015;94-101.

3. AF A. Hubungan tingkat pengetahuan pengeloaan obat terhadap pengelolaan obat di Puskesmas. J Manaj dan Pelayanan Farm. 2016;6(4).

4. Suryawati S AE. Pengaruh ketersediaan dana kontan terhadap pengadaan dan penggunaan obat tingkat Puskesmas. J Manaj Pelayanan Kesehat. 2001;4(1).

5. MJ H. Hubungan ketersediaan tenaga kefarmasian dengan karakteristik Puskesmas dan praktik kefarmasian di Puskesmas. Badan Litbangkes Kemenkes RI. 2013;

6. Dinas Kesehatan Provinsi Jawa Barat. Data Dasar Puskesmas Jawa Barat. Jakarta: Kementerian Kesehatan RI; 2016.

7. S A. Kemampuan petugas menggunakan pedoman evaluasi pengelolaan dan pembiayaan obat sebelum dan sesudah pelatihan. Majalah Kesehatan Masyarakat. 2006;11-8.

8. Sugiyono. Metode penelitian kuantitatif dan kualitatif R\&D. Bandung: Alfabeta; 2015.

9. Kemdikbud. Undang-undang Republik Indonesia Nomor 20 Tahun 2003 tentang Sistem Pendidikan Nasional [Internet]. [cited 2019 Jan 11]. Available from: http//www.simkeu.kemdikbud.go.id

10. Notoatmodjo soekidjo. Promosi kesehatan dan perilaku kesehatan. Jakarta: Rineka Cipta; 2012.

11. Waluyo Y, Athiyah U, Nurul Rochmah T. Analisis Faktor yang Mempengaruhi Pengelolaan Obat Publik di Instalasi Farmasi Kabupaten (Studi di Papua Wilayah Selatan) District Pharmacy Installation (Study in Southern Papua Area). J Ilmu Kefarmasian Indonesia. 2014;13(1):94-101. 